\title{
PUTATIVE METABOLIC PATHWAY OF MANNITOL AND SORBITOL IN SUGARCANE
}

\author{
Celso Luís Marino*; Susi Meire Maximino Leite; Ana Paula Cazerta Farro; Flávio Tetsuo Sassaki; \\ Henrique Luis Veronezi de Campos; Virgínia Elias Coscrato \\ UNESP/IV - Depto. de Genética, C.P. 510 - 18618-000, Botucatu, SP - Brasil. \\ * Corresponding author <clmarino@ibb.unesp.br>
}

\begin{abstract}
Until the mid 1950s, boron was believed to play an important role in the transport of sugars in plants. However, boron actually depends on sugar alcohols to be taken up by the plant. In some cases, the main sugars involved in this process are sorbitol and mannitol which form stable complexes with boron. In this study, the sequences of the SugarCane EST Genome Project (SUCEST) database were searched for enzymes involved in the metabolism of these sugars by comparing them with enzymes from other organisms. Eighteen contigs from sugarcane (Saccharum sp.) presented high similarity with 11 enzymes involved in the putative biosynthetic pathway of sorbitol and mannitol from fructose in sugarcane. Seven of these contigs had high homology with sequences deposited in GenBank.
\end{abstract}

Key words: boron, expressed sequence tags (ESTs), polyols, sugar alcohol

\section{PROVÁVEL VIA METABÓLICA DE MANITOL E SORBITOL EM CANA-DE-AÇÚCAR}

\begin{abstract}
RESUMO: Até meados da década de 50 acreditava-se que o boro tinha uma importante função no transporte de açúcares em plantas. Na verdade, o boro depende de açúcares álcoois para serem mobilizados dentro da planta. Em alguns organismos os principais açúcares envolvidos neste processo são o sorbitol e o manitol, que formam complexos estáveis com o micronutriente. $\mathrm{O}$ objetivo deste estudo foi procurar seqüências no banco de dados SugarCane EST Genome Project (SUCEST) que codificam enzimas participantes na via metabólica destes açúcares através da comparação de enzimas de outros organismos. Dezoito "contigs" de cana-de-açúcar (Saccharum sp.) apresentaram similaridade com onze seqüências de enzimas que compõem a provável via metabólica de sorbitol e manitol a partir de frutose. Destes “contigs”, sete apresentaram uma alta similaridade entre as seqüências depositadas no GenBank.

Palavras-chave: boro, polióis, seqüências alvos expressas (ESTs), açúcares-álcoois
\end{abstract}

\section{INTROTUCTION}

Carbohydrate chemistry has seen many advances in the last decades. Up to 1953, only four amino sugars had been identified. Almost 20 years later, about 50 amino sugars were known (Sharon, 1975). The current interest in carbohydrate chemistry is not surprising considering their importance in most aspects of the environment.

Polyols are reduced forms of ketoses that occur in more than 100 species of plants (Stoop et al., 1996). Derivatives of sorbitol and mannitol are the most common polyols. Bieleski (1982) estimated that up to $30 \%$ of the carbon fixed by plants is in the form of polyols. The occurrence of phloem mobile, boron-polyol complexes provides a mechanistic explanation for the phloem mobility of boron, observed in celery and peach. Polyols are also important in other Prunus, Malus and Pyrus species, as well as in members of the Apiaceae, Oleaceae and Celestraceae families (Brown \& Shelp, 1997).
Recent work has located a gene - BOR1 - in Arabidopsis thaliana that codifies a boron transporter enzyme thus providing a molecular basis for the active transport of this element in higher plants (Takano et al., 2002). Boron is a member of the metalloid group of elements, which also includes silicon and germanium. These elements show intermediate properties between metal and nonmetals. The role of boron in plant nutrition is still the least understood of all the mineral nutrients, but is believed to be involved in several processes, including sugar transport, cell wall synthesis, lignification, cell wall structure, carbohydrate metabolism, RNA metabolism, respiration, metabolism of indole acetic acid (AIA), phenol metabolism, and membrane stability. This indicates that boron is probably involved in a number of metabolic pathways, or may have a "cascade effect", similar to phytohormones (Marshner, 1995).

Although boron is usually immobile in the phloem, of species in which sorbitol is the major sugar, boron is mobile (Brown \& Hu, 1996). Sorbitol forms six 
stable boron:sorbitol complexes (1:2 ratio) as a result of the favorable zigzag arrangement of the 2-, 3-, and 4-hydroxyls. The stability of these sorbitol complexes exceeds that of the 3, 4, 3', 4' mannitol complex (Makkee et al., 1985; Nose \& Zenki, 1991). At the high sugar:boron ratios found in high sorbitol genera (Pyrus, Malus, Prunus), more than $99 \%$ of boron occurs in 1:2 complexes. Hu et al. (1997) used matrix-assisted, laser desorption/Fourier transform mass spectrometry to identify the 3,4-mannitol-boron-3', 4'-mannitol complex in the phloem sap of celery, as well as similar sorbitol and fructose complexes in the extrafloral nectar of peach.

The objective of this work was to use the SUCEST database to identify orthologous sugarcane genes that could codify enzymes involved in the metabolism of sorbitol and mannitol.

\section{MATERIAL AND METHODS}

\section{Enzyme detection}

The Metabolic Pathways link at http:// www.genome.ad.jp/kegg/kegg2.html was used to search for enzymes involved in the metabolism of sorbitol and mannitol. Enzymes found occurred in five pathways: glycolysis (MAP00010), the pentose phosphate cycle (MAP00030), starch and sucrose metabolism (MAP00500), fructose and mannose metabolism (MAP00051), and galactose metabolism (MAP00052). The Expasy database (http://www.expasy.ch) from the link Swiss-Prot was used to identify the catalytic activity of the enzymes and the organism with the lowest e-value from the compared sequences. Additional information was obtained from the PubMed database (http:// www.ncbi.nlm.nih.gov/).

\section{Identification of sugarcane cluster consensi}

Sugarcane EST cluster consensi were identified using the basic local alignment search tool (tBLASTn) (Altschul et al., 1990). Sugarcane reads related to the metabolism of mannitol and sorbitol were annotated using the minimum criteria of e-value $<-70$ and identity $>$ $60 \%$. The contigs identified were represented using the nomenclature created by SUCEST. The $5^{\text {th }}$ and $6^{\text {th }}$ letters in the identified contigs determined the tissue used in the construction of the libraries, e.g., RT for root (Table 1). For more details see http://sucest.lad.dcc.unicamp.br/en.

\section{Data normalization}

The frequencies of reads for each tissue in the selected contigs were computed and normalized for each enzyme. The total number of corresponding reads for each enzyme of a specific library was divided by the total number of reads for this same library, and then multiplied by 100,000 (Table 3).
Table 1 - Tissues used to construct the SUCEST libraries and their abbreviations.

\begin{tabular}{ll}
\hline Abbreviation & Tissue \\
\hline AD & $\begin{array}{l}\text { Acetobacter diazotrophicus infected } \\
\text { plantlets }\end{array}$ \\
AM & Apical meristem \\
CL & Callus \\
FL & Flowers \\
HR & $\begin{array}{l}\text { Herbaspirillum rubrisubalbicans infected } \\
\text { plantlets }\end{array}$ \\
LB & Lateral bud \\
LV & Leaves (etiolated) \\
LR & Leaf roll \\
RT & Root \\
RZ & Leaf-root transition zone \\
SB & Stem bark \\
SD & Seed \\
ST & Stem \\
\hline
\end{tabular}

\section{RESULTS AND DISCUSSION}

\section{Search for orthologous genes}

The SUCEST database (http://sucest.lad. dcc.unicamp.br/en) was mined for sugarcane gene products potentially involved in the metabolism of sorbitol and mannitol. Eleven enzymes were identified and 18 corresponding contigs were annotated (Table 2). The searching criteria (e-value and identity) allowed the annotation of only a few contigs per enzyme. However, these contigs presented high levels of similarity. In $84 \%$ of the cases, the e-value was less than -100 , whereas in $37 \%$ of the cases it was 0.0 (Table 2).

During the search, the level of similarity to microorganism genes was frequently low. This could explain the high e-value observed for the enzyme mannitol dehydrogenase, which was not found in higher organisms. Although the e-values for this enzyme were very high, the enzyme must be present in sugarcane since polyol mannitol has been detected in fresh sugarcane leaves at a concentration of $0.02 \mathrm{~mol} \mathrm{~L}^{-1}$ using high performance anion exchange-pulse amperometric detection (HPAEPAD) at COPERSUCAR ${ }^{1}$; sorbitol has also been detected at a concentration of $0.04 \mathrm{~mol} \mathrm{~L}^{-1}$. The highest levels of identity were observed with genes from maize (Zea mays), also a gramineous plant (Table 2).

Out the 11 enzymes annotated, aldehyde reductase and mannitol dehydrogenase showed a single contig represented by only one read. The single read in aldehyde reductase could be related to a sugarcane database representation or to a higher gene expression in seedlings

\footnotetext{
${ }^{1}$ Eugênio C. Ulian - Personal communication, Copersucar, Piracicaba, SP, Brazil.
} 
Table 2 - Enzyme Code number, name, reaction catalyzed from enzymes and reads found in sugarcane related to the metabolic pathway of mannitol and sorbitol.

\begin{tabular}{|c|c|c|c|c|c|c|c|c|}
\hline E.C. & Name & Reaction & Organism & Contigs & $\mathrm{Gi}$ & e-value & Identity & Accession* \\
\hline 1.1 .1 .21 & Aldehyde reductase & $\begin{array}{l}\text { Alditol+ } \\
\text { NAD }(\mathrm{P})(+) \leftrightarrow \\
\text { aldose }+ \\
\text { NAD }(\mathrm{P}) \mathrm{H}\end{array}$ & $\begin{array}{l}\text { Hordeum } \\
\text { vulgare }\end{array}$ & SCEPSD2070C10.g & 113595 & e-101 & $82 \%$ & P23901 \\
\hline 3.2 .1 .26 & Beta-fructofuranosidase & $\begin{array}{l}\text { Sucrose 6-P } \rightarrow \\
\text { A-D-glucose 6-P }\end{array}$ & Zea mays & $\begin{array}{l}\text { SCCCST3006A04.g } \\
\text { SCCCCL5071D07.g }\end{array}$ & $\begin{array}{l}7435471 \\
1352469\end{array}$ & $\begin{array}{c}0.0 \\
\mathrm{e}-92\end{array}$ & $\begin{array}{l}91 \% \\
80 \%\end{array}$ & $\begin{array}{l}\text { T02260 } \\
\text { P49174 }\end{array}$ \\
\hline 3.2 .1 .20 & Alpha-glucosidase & $\begin{array}{l}\text { Sucrose } \rightarrow \text { B-D- } \\
\text { fructose }\end{array}$ & $\begin{array}{l}\text { Hordeum } \\
\text { vulgare }\end{array}$ & SCJLRT1020A08.g & 8547062 & 0.0 & $78 \%$ & AAF76254 \\
\hline 2.7.1.4 & Fructokinase & $\begin{array}{l}\text { B-D-fructose } \leftrightarrow \\
\text { B-D fructose } 6-\mathrm{P}\end{array}$ & $\begin{array}{l}\text { Arabidopsis } \\
\text { thaliana }\end{array}$ & $\begin{array}{c}\text { SCCCCL3120B01.g } \\
\text { SCJLRZ1021E10.g } \\
\text { SCEPAM2013E06.g }\end{array}$ & $\begin{array}{l}7434221 \\
7434221 \\
2322265\end{array}$ & $\begin{array}{l}e-138 \\
e-131 \\
e-130\end{array}$ & $\begin{array}{l}73 \% \\
73 \% \\
62 \%\end{array}$ & $\begin{array}{c}\text { T01971 } \\
\text { T01971 } \\
\text { AAG51160 }\end{array}$ \\
\hline 2.7.1.1 & Hexokinase & $\begin{array}{l}\text { ATP + D- } \\
\text { hexose } \leftrightarrow \text { ADP } \\
+ \text { D-hexose 6- } \\
\text { phosphate }\end{array}$ & $\begin{array}{c}\text { Citrus } \\
\text { sinensis } \\
\text { Oryza sativa }\end{array}$ & $\begin{array}{l}\text { SCEZLB1008B10.g } \\
\text { SCAGLR2018E09.g }\end{array}$ & $\begin{array}{l}1106621 \\
9049460\end{array}$ & $\begin{array}{c}\mathrm{e}-167 \\
0.0\end{array}$ & $\begin{array}{l}71 \% \\
76 \%\end{array}$ & $\begin{array}{l}\text { AAG2850 } \\
\text { BAA99425 }\end{array}$ \\
\hline 2.4 .1 .14 & $\begin{array}{l}\text { Sucrose-phosphate } \\
\text { synthase }\end{array}$ & $\begin{array}{l}\text { D-fructose 6- } \\
\text { phosphate } \leftrightarrow \\
\text { sucrose 6- } \\
\text { phosphate }\end{array}$ & Oryza sativa & SCEQAM1036A06.g & 7433840 & 0.0 & $75 \%$ & T04103 \\
\hline 1.1 .1 .138 & $\begin{array}{l}\text { Mannitol - } \\
\text { dehydrogenase } \\
\text { (NADP+). }\end{array}$ & $\begin{array}{l}\text { D-mannitol + } \\
\text { NADP }(+) \leftrightarrow \\
\text { D-fructose }+ \\
\text { NADPH }\end{array}$ & $\begin{array}{l}\text { Uromyces } \\
\text { fabae } \\
\text { Agaricus } \\
\text { bisporus }\end{array}$ & SCBFRT1071H10.g & $\begin{array}{r}6093715 \\
12230338\end{array}$ & $\begin{array}{l}e-21 \\
e-25\end{array}$ & $\begin{array}{l}27 \% \\
31 \%\end{array}$ & $\begin{array}{l}\text { O00058 } \\
\text { O93868 }\end{array}$ \\
\hline 3.1 .3 .24 & Sucrose-phosphatase & $\begin{array}{l}\text { Sucrose 6-P } \rightarrow \\
\text { sucrose }\end{array}$ & Zea mays & $\begin{array}{l}\text { SCSBST3096E12.g } \\
\text { SCQGLB2045H04.g }\end{array}$ & $\begin{array}{c}1112775 \\
11127755\end{array}$ & $\begin{array}{l}e-112 \\
e-73\end{array}$ & $\begin{array}{l}96 \% \\
60 \%\end{array}$ & $\begin{array}{l}\text { AAG31074 } \\
\text { AAG31074 }\end{array}$ \\
\hline 53.9 & Glucose-6-phosphate & B-D-fructose $\leftrightarrow$ & $\begin{array}{l}\text { Spinacia } \\
\text { oleraceae }\end{array}$ & SCEQRT1029D09.g & 7484671 & 0.0 & $80 \%$ & T09153 \\
\hline & isomerase & A-D-glucose 6-P & & SCJFRT1060F09.g ${ }^{1}$ & 1346073 & 0.0 & $95 \%$ & P49105 \\
\hline 2.4.1.99 & $\begin{array}{l}\text { Sucrose } 1 \mathrm{~F}- \\
\text { fructosyltransferase }\end{array}$ & $\begin{array}{l}\text { Sucrose }+ \\
\text { sucrose } \leftrightarrow \text { D- } \\
\text { glucose }+1 \mathrm{~F} \text { - } \\
\text { beta-D-fructosyl- } \\
\text { sucrose }\end{array}$ & $\begin{array}{c}\text { Festuca } \\
\text { arundinacea }\end{array}$ & $\begin{array}{l}\text { SCCCST3006A04.g } \\
\text { SCCCLR1C07F04.g }\end{array}$ & $\begin{array}{l}9929165 \\
9929165\end{array}$ & $\begin{array}{l}0.0 \\
\mathrm{e}-118\end{array}$ & $\begin{array}{l}66 \% \\
66 \%\end{array}$ & $\begin{array}{l}\text { CAC05261 } \\
\text { CAC05261 }\end{array}$ \\
\hline 1.1 .1 .200 & $\begin{array}{l}\text { Aldose-6-phosphate } \\
\text { reductase (NADPH) }\end{array}$ & $\begin{array}{l}\text { D-sorbitol 6- } \\
\text { phosphate + } \\
\text { NADP(+) } \rightarrow \text { D- } \\
\text { glucose 6- } \\
\text { phosphate + } \\
\text { NADPH }\end{array}$ & $\begin{array}{c}\text { Malus } \\
\text { domestica }\end{array}$ & $\begin{array}{l}\text { SCCCL3120A08.b } \\
\text { SCJLRZ1020H04.g }\end{array}$ & $\begin{array}{l}134153 \\
134153\end{array}$ & $\begin{array}{l}\mathrm{e}-111 \\
\mathrm{e}-109\end{array}$ & $\begin{array}{l}66 \% \\
68 \%\end{array}$ & $\begin{array}{l}\text { P28475 } \\
\text { P28475 }\end{array}$ \\
\hline
\end{tabular}

*Accession numbers are referent to the organisms searched at site http://www.ncbi.nlm.nih.gov/.

${ }^{1}$ Read without contig.

in relation to isolated tissues, since the read was found only in the first case. In the case of mannitol dehydrogenase, the read was identified in the root. An explanation for this could be that the level of mannitol is so low that it could not be detected in the sugarcane database (SUCEST). In the remaining enzymes, the contigs were formed by reads from more than one type of tissue. Three contigs were annotated for fructokinase. One of these had 96 reads which may indicate that this enzyme figured was the most abundant (Figure 1).

All of the 13 tissues used to construct the different SUCEST libraries contain sugarcane sequences related to the examined metabolic pathway. The contribu-

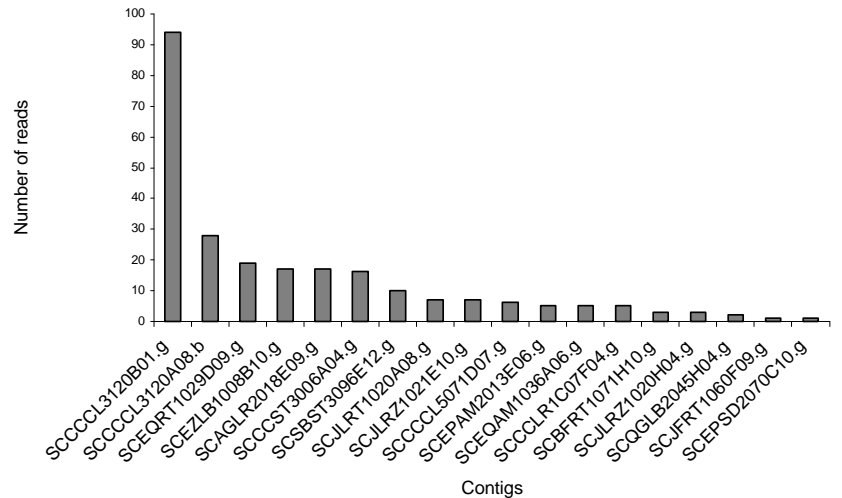

Figure 1 - Distribution of sugarcane reads per contig. 
Table 3 - Frequency and percentage of reads for each tissue in selected contigs. Data were normalized by dividing the total number of corresponding reads for each enzyme of a specific library by the total number of reads for this same library, and multiplying the resulting quotient by 100,000 .

\begin{tabular}{|c|c|c|c|c|c|c|c|c|c|c|c|c|c|c|}
\hline E.C. & $\mathrm{AM}$ & FL & LV & SB & ST & LR & RT & CL & LB & $\mathrm{RZ}$ & SD & $\mathrm{AD}$ & HR & TOTAL \\
\hline Total reads & 28128 & 64095 & 6432 & 16318 & 20762 & 18141 & 31487 & 11872 & 18047 & 24096 & 21406 & 18137 & 12000 & \\
\hline \multirow[t]{2}{*}{1.1 .1 .138} & 0.00 & 0.00 & 0.00 & 0.00 & 0.00 & 0.00 & 3.18 & 0.00 & 0.00 & 0.00 & 4.67 & 5.51 & 0.00 & 13.36 \\
\hline & $(0.00 \%)$ & $(0.00 \%)$ & $(0.00 \%)$ & $(0.00 \%)$ & $(0.00 \%)$ & $(0.00 \%)$ & $(23.77 \%)$ & $(0.00 \%)$ & $(0.00 \%)$ & $(0.00 \%)$ & $(34.96 \%)$ & $(41.27 \%)$ & $(0.00 \%)$ & \\
\hline \multirow[t]{2}{*}{2.7 .1 .4} & 63.99 & 37.44 & 46.64 & 73.54 & 81.88 & 5.51 & 38.11 & 42.12 & 27.71 & 16.60 & 4.67 & 22.05 & 16.67 & 476.94 \\
\hline & $(13.42 \%)$ & $(7.85 \%)$ & $(9.78 \%)$ & $(15.42 \%)$ & $(17.17 \%)$ & $(1.16 \%)$ & $(7.99 \%)$ & $(8.83 \%)$ & $(5.81 \%)$ & $(3.48 \%)$ & $(0.98 \%)$ & $(4.62 \%)$ & $(3.49 \%)$ & \\
\hline \multirow[t]{2}{*}{1.1 .1 .200} & 3.56 & 6.24 & 15.55 & 6.13 & 14.45 & 0.00 & 15.88 & 8.42 & 16.62 & 12.45 & 32.70 & 11.03 & 0.00 & 143.02 \\
\hline & $(2.49 \%)$ & $(4.36 \%)$ & $(10.87 \%)$ & $(4.28 \%)$ & $(10.10 \%)$ & $(0.00 \%)$ & $(11.10 \%)$ & $(5.89 \%)$ & $(11.62 \%)$ & $(8.70 \%)$ & $(22.86 \%)$ & $(7.71 \%)$ & $(0.00 \%)$ & \\
\hline \multirow[t]{2}{*}{3.2 .1 .26} & 3.56 & 4.68 & 15.55 & 0.00 & 43.35 & 0.00 & 9.53 & 8.42 & 0.00 & 0.00 & 4.67 & 16.54 & 0.00 & 106.30 \\
\hline & $(3.34 \%)$ & $(4.40 \%)$ & $(14.63 \%)$ & $(0.00 \%)$ & $(40.78 \%)$ & $(0.00 \%)$ & $(8.96 \%)$ & $(7.92 \%)$ & $(0.00 \%)$ & $(0.00 \%)$ & $(4.39 \%)$ & $(15.56 \%)$ & $(0.00 \%)$ & \\
\hline \multirow[t]{2}{*}{2.4 .1 .99} & 0.00 & 4.68 & 15.55 & 18.38 & 43.35 & 16.54 & 15.88 & 0.00 & 0.00 & 0.00 & 0.00 & 0.00 & 0.00 & 114.38 \\
\hline & $(0.00 \%)$ & $(4.09 \%)$ & $(13.59 \%)$ & $(16.07 \%)$ & $(37.90 \%)$ & $(14.46 \%)$ & $(13.88 \%)$ & $(0.00 \%)$ & $(0.00 \%)$ & $(0.00 \%)$ & $(0.00 \%)$ & $(0.00 \%)$ & $(0.00 \%)$ & \\
\hline \multirow[t]{2}{*}{1.1 .1 .21} & 0.00 & 0.00 & 0.00 & 0.00 & 0.00 & 0.00 & 0.00 & 0.00 & 0.00 & 0.00 & 4.67 & 0.00 & 0.00 & 4.67 \\
\hline & $(0.00 \%)$ & $(0.00 \%)$ & $(0.00 \%)$ & $(0.00 \%)$ & $(0.00 \%)$ & $(0.00 \%)$ & $(0.00 \%)$ & $(0.00 \%)$ & $(0.00 \%)$ & $(0.00 \%)$ & $(100.00 \%)$ & $(0.00 \%)$ & $(0.00 \%)$ & \\
\hline \multirow[t]{2}{*}{2.4 .1 .14} & 3.56 & 0.00 & 15.55 & 0.00 & 0.00 & 0.00 & 0.00 & 0.00 & 0.00 & 4.15 & 4.67 & 0.00 & 8.33 & 36.26 \\
\hline & $(9.81 \%)$ & $(0.00 \%)$ & $(42.88 \%)$ & $(0.00 \%)$ & $(0.00 \%)$ & $(0.00 \%)$ & $(0.00 \%)$ & $(0.00 \%)$ & $(0.00 \%)$ & $(11.45 \%)$ & $(12.88 \%)$ & $(0.00 \%)$ & $(22.98 \%)$ & \\
\hline \multirow[t]{2}{*}{5.3 .1 .9} & 21.33 & 4.68 & 0.00 & 6.13 & 0.00 & 5.51 & 6.35 & 0.00 & 11.08 & 0.00 & 0.00 & 0.00 & 0.00 & 55.09 \\
\hline & $(38.72 \%)$ & $(8.50 \%)$ & $(0.00 \%)$ & $(11.12 \%)$ & $(0.00 \%)$ & $(10.01 \%)$ & $(11.53 \%)$ & $(0.00 \%)$ & $(20.12 \%)$ & $(0.00 \%)$ & $(0.00 \%)$ & $(0.00 \%)$ & $(0.00 \%)$ & \\
\hline \multirow[t]{2}{*}{2.7 .1 .1} & 7.11 & 9.36 & 15.55 & 18.38 & 9.63 & 5.51 & 3.18 & 25.27 & 22.16 & 8.30 & 32.70 & 5.51 & 8.33 & 171.01 \\
\hline & $(4.16 \%)$ & $(5.47 \%)$ & $(9.09 \%)$ & $(10.75 \%)$ & $(5.63 \%)$ & $(3.22 \%)$ & $(1.86 \%)$ & $(14.78 \%)$ & $(12.96 \%)$ & $(4.85 \%)$ & $(19.12 \%)$ & $(3.22 \%)$ & $(4.87 \%)$ & \\
\hline \multirow[t]{2}{*}{3.2 .1 .20} & 0.00 & 0.00 & 0.00 & 0.00 & 9.63 & 0.00 & 12.70 & 0.00 & 0.00 & 4.15 & 0.00 & 0.00 & 0.00 & 26.48671 \\
\hline & $(0.00 \%)$ & $(0.00 \%)$ & $(0.00 \%)$ & $(0.00 \%)$ & $(36.37 \%)$ & $(0.00 \%)$ & $(47.96 \%)$ & $(0.00 \%)$ & $(0.00 \%)$ & $(15.67 \%)$ & $(0.00 \%)$ & $(0.00 \%)$ & $(0.00 \%)$ & \\
\hline \multirow[t]{2}{*}{3.1 .3 .24} & 3.56 & 4.68 & 0.00 & 0.00 & 14.45 & 0.00 & 0.00 & 0.00 & 5.54 & 0.00 & 0.00 & 22.05 & 0.00 & 50.28065 \\
\hline & $(7.07 \%)$ & $(9.31 \%)$ & $(0.00 \%)$ & $(0.00 \%)$ & $(28.74 \%)$ & $(0.00 \%)$ & $(0.00 \%)$ & $(0.00 \%)$ & $(11.02 \%)$ & $(0.00 \%)$ & $(0.00 \%)$ & $(43.86 \%)$ & $(0.00 \%)$ & \\
\hline
\end{tabular}

tion of each tissue varied considerably in the selected contigs (Figure 2). A special case was contig "SCCCCL3120B01.g" which presented reads in all tissues. Based on the normalized data for all contigs, tissues with the highest frequencies were LV (1.9), ST (1.01), CL (0.84) and SB (0.76), and tissues with the lowest frequencies were LR (0.22) and FL (0.12) (Figure 2). In species that translocate polyols, vegetative tissues such as petioles, stems, and roots may accumulate polyols, but there is no evidence that this occurs by direct synthesis rather than by simple import from the phloem (Madore, 1994).

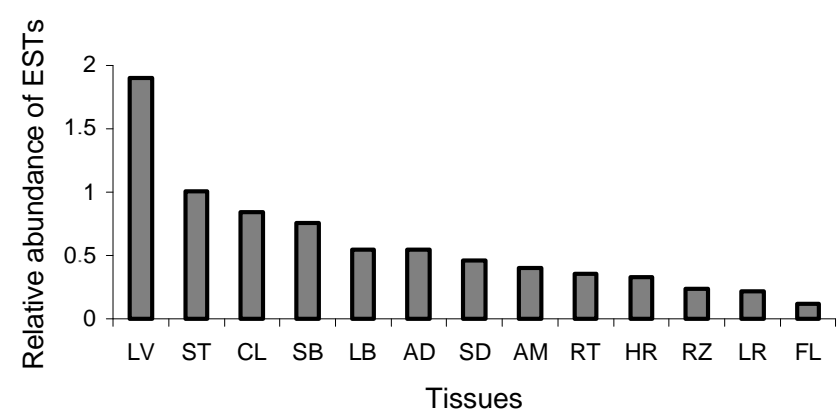

Figure 2 - Relative abundance of ESTs in different libraries. 


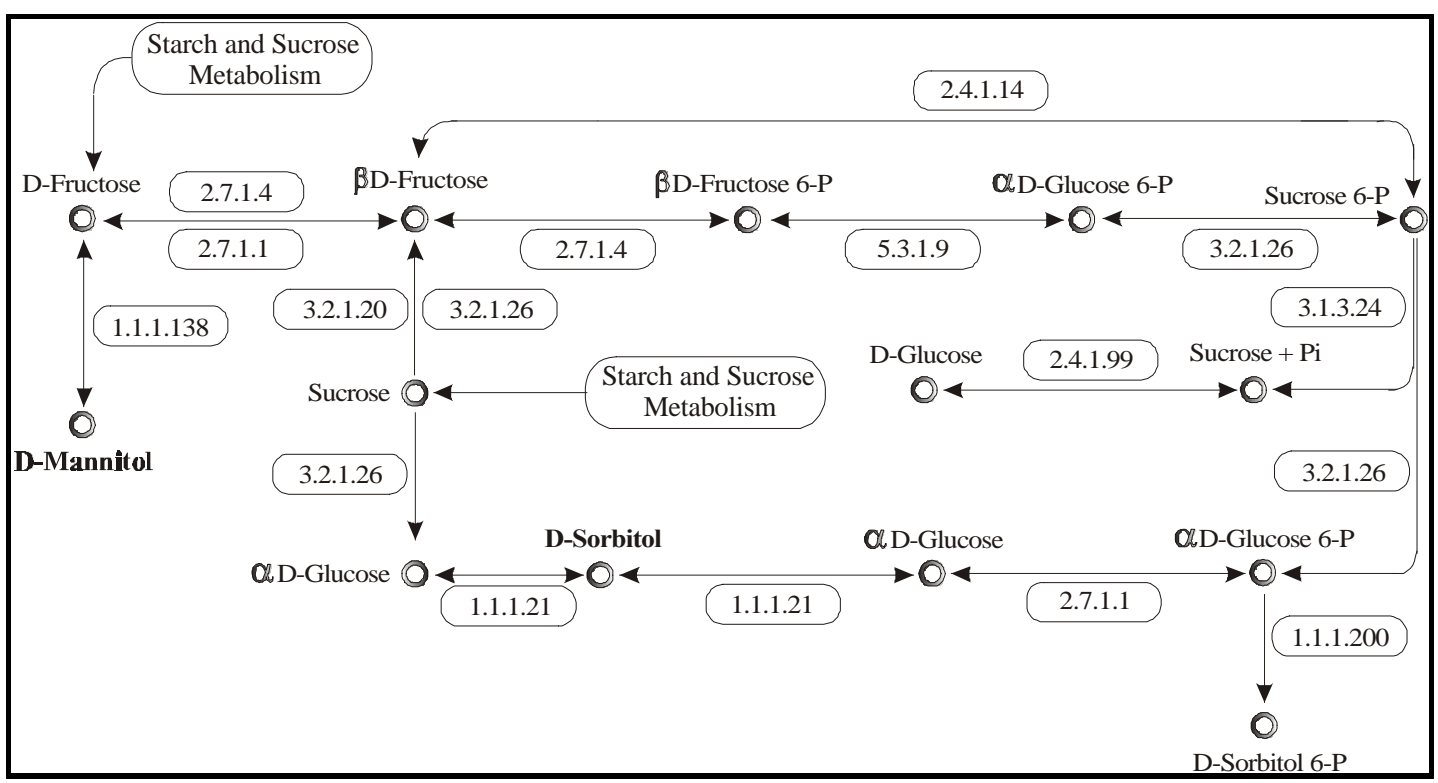

Figure 3 - Putative metabolic pathway for the synthesis of mannitol and sorbitol from fructose in sugarcane.

The enzyme (mannitol dehydrogenase) 1.1.1.138 was detected in root (RT), seed (SD) and in Acetobacter diazotrophicus infected plantlets (AD) (Table 3). The presence of this enzyme in AD could possibly explain the correlation between mannitol levels and the occurrence of a pathogen resistance gene (Yamamoto et al., 1997).

Aldehyde reductase (E.C. 1.1.1.21), which converts aD-glucose to $\mathrm{D}$-sorbitol and vice versa, shared similarity with only one contig which had a unique read found in seed (Table 3). Although sink tissues, such as seeds, may contain polyols, these are usually only trace components and not the major carbohydrates (Madore, 1994). Comparison of the relative abundance of the genes identified in the different libraries, indicated that all were present mainly in the stem (ST), leaves (LV), callus (CL) and stem bark (SB), tissues in which boron is required for the formation and elongation of cell wall membrane stability (Shelp, 1993).

\section{Construction of the metabolic pathway}

The biosynthetic pathway of mannitol and sorbitol is closely related to that of other sugars such as fructose, glucose and sucrose, and depends on some important enzymes. The first stable product of the photosynthetic process is triose phosphate, which is the immediate precursor of all carbohydrates and is synthesized in the source leaves. Other sugars, including polyols such as mannitol and sorbitol, are subsequently derived from triose phosphate.

Based on the putative plant homologues identified in the set of sugarcane ESTs used (Table 3), it was possible to construct a putative biosynthetic pathway for sorbitol and mannitol from fructose (Figure 3). This pathway was constructed based on sugarcane contigs that shared significant sequence similarity to known enzymes and had low e-value levels. With the use of less strict criteria, this pathway could be expanded.

New searches will be carried out aiming to expand this putative metabolic pathway. For that, searches for contigs related to other steps and ramifications of this proposed metabolic pathway will be made. Functional genomic studies to confirm the expression of the enzymes included in the putative biosynthetic pathway of mannitol and sorbitol, as well as biochemical studies to show that the enzymes are active in hybrids of the Saccharum complex, are now required.

\section{ACKNOWLEDGEMENTS}

To FAPESP for financial support and Dr. Ivan de Godoy Maia for help during this study.

\section{REFERENCES}

ALTSCHUL, S.F.; GISH, M.; MILLER, W.; MYERS, E.W.; LIPMAN, E.J. Basic local alignment search tool. Journal of Molecular Biology, v.215, p.403-410, 1990.

BIELESKI, R.L. Sugar alcohols. In: LOEWUS, F.A.; TANNER, W. (Ed.) Encyclopedia of plant physiology. New York: Springer-Verlag, 1982. v.13A, p.158-192.

BROWN, P.; HU, H. Phloem mobility of boron is species dependent: evidence for phloem mobility in sorbitol-rich species. Annals of Botany, v.77, p.497-505, 1996.

BROWN, P.; SHELP, B.J. Boron mobility in plants. Plant and Soil, v.193, p.85-101, 1997.

HU, H.; PENN, S.G.; LEBRILLA, C.B.; BROWN, P.H. Isolation and characterization of soluble boron-complexes in higher plants: the mechanism of phloem mobility of boron. Plant Physiology, v.113, p.649-655, 1997.

MADORE, M.A. Handbook of plant and crop physiology. In: PESSARAKLI, M. (Ed.) Carbohydrate synthesis and crop metabolism. New York: Marcel Dekker, 1994. cap.12, p.257-273.

MAKKEE, M.; KIEBOOM, A.P.G.; VAN BEKKUM, H. Studies on borate esters III. Borate esters of D-mannitol, D-glucitol, D-fructose and Dglucose in water. Recueil des Travaux des Chimique des Pays-Bas, v.104, p.230-235, 1985. 
MARSHNER, H. Mineral nutrition of higher plants. 2.ed. San Diego: Academic Press, 1995. 889p.

NOSE, K.; ZENKI, M. Flow injection spectrophotometric determination of boron with D-sorbitol using methyl orange as an indicator. Analyst, v.116, p.711-714, 1991.

SHARON, N. Complex carbohydrates: their chemistry, biosynthesis and functions. Massachusetts: Addison Wesley, 1975. 466p.

SHELP, B.J. Physiology and biochemistry of boron in plants. In: GUPTA, U.C. (Ed.) Boron and its role in crops production. Boca Raton: CRC Press, 1993. cap.4, p.53-85.

STOOP, J.M.H.; WILLIAMSON, J.D.; PHARR, D.M. Mannitol metabolism in plants: a method for coping with stress. Trends in Plant Science, v.1, p.139-144, 1996.
TAKANO, J.; NOGUCHI, K.; YASUMORI, M.; KOBAYASHI, M.; GAJDOS, Z.; MIWA, K.; HAYASHI, H.; YONEYAMA, T.; FUJIWARA, T. Arabidopsis boron transporter for xylem loading. Nature, v.420, p.337-340, 2002.

YAMAMOTO, Y.T.; ZAMSKI, E.; WILLIAMSON, J.D.; CONKLING, M.A.; PHARR, D.M. Subcellular localizationof celery mannitol dehydrogenase. A cytosolic metabolic enzyme in nuclei. Plant Physiology, v.115, p.1397-1403, 1997.

Received June 06, 2002

Accepted July 31, 2003 